\title{
CHILD PSYCHOLOGY IN THE ANCIENT WORLD: QUINTILIAN AND AUGUSTINE ON KINDERGARTEN EDUCATION
}

\author{
(Quintilian Institutio Oratoria 1.1-3, 1.11-12 and 2.1-3 \\ and Augustine Confessiones 1)
}

\begin{abstract}
Marilese van Nieuwenhuizen, Nadine Brand and Jo-Marie Claassen,
\end{abstract} University of Stellenbosch

Quintilian, as the first publicly remunerated teacher of rhetoric at Rome, occupies a unique place in the history of Classical education. His remuneration (a thousand gold pieces per annum) set a standard few Latin teachers have subsequently achieved. That is, however, not his chief claim to fame. His handbook on education, the Institutio Oratoria, in twelve books, is a model of thoroughness, treating of every topic, from the child's earliest learning experiences! to what may be considered a complete syllabus for a combined liberal university course in the humanities and sciences. It is also a handbook on good teacher-pupil relationships, parent-teacher interaction and educational ethics. It touches on all aspects of teacher conduct, even the most suitable age at which a sensible man would retire.

This first century Mr Chips left a model of educational theory and practice for others to follow. Much of what he had to say remains of value even today. If the modern student teacher were to peruse no other handbook than Quintilian's Institutiones, he or she would still emerge from such study well-equipped with educational theory and sound, commonsense educational and psychological tools. In sum, from the Instituriones the modern teacher can learn how to teach.

If we should subscribe to that naive belief in absolute familiarity with all prototypes in every ancient author with which some Quellenforschers tend to approach the Classics, we might assume a greater influence on his pedagogic successors than Quintilian actually had. Judging from Augustine's Confessiones, written some three centuries later, very few of the sound educational principles advocated by Quintilian ever reached the North African shores. 2 In the first few chapters of the Confessiones we have what may be termed a "worm's eye view" of Augustine's pedagogical experiences as a child, and they were often unfortunate. From Augustine's Confessiones the modern teacher may learn how not to teach.

Augustine tells of his own sufferings at school. "Non amabam litteras et me in eas urgeri

1 Manson 1983 rightly points out that Quintilian was aware of the novelty of advocating education from an earlier age than seven.

2 At a Roman Studies conference, beld at the university of Natal in Durban, July 1992, Dr Fabian Opeku of Cape Coast University, Ghana, discussing the nature of education in Africa Proconsularis in the second century (since published in Scholia NS 2 (1993), 31-44), emphasised the role played by Apuleius in systemisation of instructional material, which made Carthage a suitable centre with sufficient facilities for the full higher education of Africa's men of letters, such as Minucius Felix, Tertullian, Cyprian and Augustine, but this has to do with scademic excellence, and not with child psychology. 
oderam; et urgebar tamen èt bene mihi fiebat, nec faciebam ego bene: non enim discerem, nisi cogerer. nemo enim invitus bene facit, etiamsi bonum est quod facit" (I did not like my studies and I hated being forced to do them; however I was also forced, and this was to my advantage, and yet I didn't do well: for I wouldn't study unless I was forced. For noone does well if he does something unwillingly, even if what he does is good.) (Conf. 1.19). Poor little Augustine's hatred of school seems to have stemmed from the force and violence of his mentors. In modern terminology, force not only creates fear, it also creates a dislike for the subject in the child. When these factors are combined, an affective filter is formed (Richards 1986:133). ${ }^{3}$

So Augustine's unfortunate experiences as a small pupil most certainly formed, by contrast, the adult author's pedagogical convictions, influencing, by default, what he thought proper education should comprize. Yet he discounts his sufferings against the value that his education holds for him as an adult. To Augustine "Education is always a good thing; its opposite, ignorance, is therefore evil" (Howie 1969b:28). Education is a "human activity of the greatest significance. Education supplies nourishment for the soul ... and is a method by which human beings grow in a real understanding of themselves and their destiny" (Howie 1969b:143,181). Augustine's retrospect on his own education tempers what he has to say. What we may deduce about his general views on education may equally well be couched in modern pedagogical terminology.

This study sets out to compare Quintilian's educational precepts, developed through years of experience as a teacher, with Augustine's theories of education, based on his own negative experiences. At the same time, by reference to aspects of a modern syllabus for teacher training, we intend to show that both Quintilian and Augustine offer pedagogical advice which is as sound and relevant today as it was in their time.

\section{THE ROLE OF PARENTS IN A CHILD'S UPBRINGING}

Quintilian notes that a child learns and studies as a totality - his body, mind, senses, emotions, background knowledge, even his social origins play a part. Everything that makes a specific child unique influences the way in which the child studies and his attitude towards his studies.4 In education today a similar emphasis is placed on the child as an entity (de Vries 1978:39). It is accepted that not just the brain and intellect of the child is the object of education, but that its "affective domain" and ecological systems must be taken into account, also its history of success or failure in a particular subject. Its home background is of paramount importance.

Augustine was equally aware of this and he cautions that the learning environment must be friendly, warm and safe, otherwise learning will not take place. He bases this on his own terror when learning Greek, contrasting it with the ease with which he absorbed his mother

3 An affective filter is caused by fear and anxiety. These emotions "short" the neo-cortex of the brain which is responsible for intricate and complex reasoning. The affective filter prevents input from taking place, causing a "blank". (Affective filter Hypothesis - Richards \& Rogers 1986:133)

4 He notes that temperament has a great deal to do with the way a pupil will approach his studies, and that a dispirited boy will not display eagemess for study: "neque illum tristem semperque demissum sperare possim erectae circa studia mentis fore..." [Nor should I be able to hope that, if he is always miserable because he has been put down, he would be enthusiastic (of alert mind) about his studies] (Inst. Or. 1.3.10).

5 The child's "ecological system" is the world and circumstances it lives in (De Vries 1978:39). 
tongue: "nulla enim verba illa noveram et saevis terroribus ac poenis, ut nossem, instabatur mihi vehementer. nam et Latina aliquando infans utique nulla noveram et tamen advertendo didici sine ullo metu atque cruciatu inter etiam blandimenta nutricum et ioca adridentium et laetititas adludentium. didici vero illa sine poenali onere urgentium, cum me urgeret cor meum ad parienda concepta sua, atque ea nata non essent, nisi aliqua verba didicissem non a docentibus, sed a loquentibus, in quorum et ego auribus parturiebam quidquid sentiebam. hinc satis elucet maiorem habere vim ad discenda ista liberam curiositatem quam meticulosam necessitatem" [For not one word of it (Greek) did I understand, and to make me understand I was urged on vehemently with cruel threats and punishments. There also was a time when (as an infant) I knew no Latin; but I learned it without fear of suffering, by mere observation, in the cuddles of my nannies and the fun and laughter and happiness of playmates. I learned it without any burden of punishment looming over me, while my heart encouraged me to bring forth what it had conceived, and those words would not have been produced if I had learned them from teachers, instead of from people who spoke to me, in whose ears I could give birth to the thoughts I had conceived. From this it is clear enough that our free curiosity has greater power to help us learn those things than rigid force does] (Conf. 1.23). Augustine's statements are comparable to methods used in contemporary second and foreign language teaching (Richards \& Rogers 1986:137-139).6

Quintilian values the role of the parents - both father and mother. First, parents must love, care for and pay attention to the child, that is, meet its most basic needs. He argues that boys who do not react well to education have become dull because they were deprived of the necessary attention in their first years, and he urges parents to cherish their future little "orator" carefully from birth onward (Inst. Or. 1.1.2-3). The need for love, care and attention is the third of the basic needs identified by Maslow. Satisfactory fulfillment of the third basic need presupposes that the first two - physiological needs and the need for safety - have been met.7 Augustine also emphasises the fact that children have certain needs, some more basic than others, citing babies' instinctive ability to suckle, and their reactions to comfort or discomfort (Conf. 1.7).8 This is in line with modern psychological theory as embodied, for instance, in Bloom's or Maslow's hierarchical taxonomies of basic needs. These needs are met primarily in the home (De Vries 1978:67).

It is clear that Quintilian believed that education should first and foremost be child-centred. This is in line with the modern concept that parents to a large extent determine the child's upbringing and that classroom education for small children should be an extension of the home. In a warm, loving, relaxed, fearless environment, where the child is rewarded for every effort, effective learning takes place. This environment may be contrasted with the traditional school environment, which is impersonal and critical, and where error is emphasized and little reward is given. Augustine experienced both kinds of education. In Conf. 1.13 he describes how he imagines, extrapolating from the example of other children, how he learnt to speak. He ends 13 with the remark that he entered life communicationg with those around him, "pendens ex parentum auctoritate nutuque maiorum hominum" (dependent on parental authority and the decisions of my elders). This suggests that little Augustine's need to feel safe was largely met, in spite of what he

6 The teacher's role in teaching a foreign language according to the Communicative or Narural Approach, a method usually ascribed to Krashen and Terrell.

7 The first level in Maslow's hierarchy consists of physiological needs such as the need for food and shelter. Hunger indicates that the body "needs" food for energy. Thirst indicates that the body "needs" liquid. These needs underpin the will to survive. If they are not met, all other needs become irrelevant. 
subsequently relates about his frequent negative experiences in the classroom.8

There is a large body of modern research on the influence of positive or negative expectations on behavioral change. Experiments have for instance shown that pupils in school have a tendency to perform as they are expected to perform. In a well-known example pupils from whom teachers had been led to expect it showed considerably more intellectual gain than did the other children in the same school (Rosenthal \& Jacobson 1986). The same principle applies in Quintilian's view that parents should have positive expectations of their child. He urges every new father to expect great things of his baby son, for then he will more diligently urge him on toward greatness: "Igitur nato filio pater spem de illo primum quam optimam capiat, ita diligentior a principiis fiet" [Therefore, when a son is born, let the father first and foremost cherish (great) hope(s) about him, that he may in this way become so much more diligent from the outset] (Inst. Or. 1.1.1). When the parents' attitude towards the child is supportive, their attitude will be encouraging and helpful. The child will in its turn strive harder to be cooperative because it recognizes its parents' positive concern.

Because both parents play a determining role in its education, parents clearly are the most important people in a child's life - therefore they must set an example worth following and maintain high moral standards (De Vries 1978:39). According to Quintilian not only the parents, but also other adults such as nurses and paedagogi, should set an academic example worth following.9 To set a good example, the adult, whether a parent or slave, should be of good character, for that is without doubt the most important consideration: "morum quidem in his haud dubie prior ratio est" (Inst. Or. 1.1.4).10 That is not all a child needs: parents should also bolster its conception of self. Sadly, from what we read of his elders' treatment of the infant Augustine, his parents appear sometimes to have acted rather cruelly, a judgement about the saintly Monica that is not always sufficiently noted. Loving as his parents were, it would appear that they did not always consider the feelings of their little charge. In modern terminology, they did not consider his need for esteem

8 Only when a child' safety needs have been met, it has the boldness to explore on its own, but with the knowledge that its parents are there to help and protect it. Exploration leads to emancipation, when the child has the confidence to explore the world on its own without parental overseeing. Vide Augustine's comments on his awareness of his mother's care and love for him in Conf. 1.9.17. Yet later he deplores the lack of moral oversight in his teens which resulted in his early sexual licence, while his elders were still assiduously guiding his intellectual well-being (Conf. 2.2-4). Another example of Augustine's safety needs being met, is in his mother's care and love for him- "Thou sawest, my God, with what eagerness and what faith I sought, from the pious care of my mother...the baptism of Thy Christ my God and Lord. Whereupon the mother of my flesh, being much troubled, (since, with a heart pure in Thy faith, she even more lovingly travailed in birth of my salvation), would in eager haste have provided for my consecration and cleansing..." (Conf. 1.9.17).

$9 \quad$ About the child's parents Quintilian says: "In parentibus vero quam plurimum esse eruditionis optaverim, nec de patribus tantum loquor," that is, he would encourage an academic background in both parents (Inst. Or. 1.1.6) and of paedagogi he adds: "de paedagogis hoc amplius, ut aut sint eruditi plene, quam primam esse curam velim, aut se non esse eruditos sciant" - they should either be well-educated, or eise aware of their own academic shortcomings (Inst. Or. 1.1.8).

10 In 1.2.6-8 Quintilian censures the influence of parents who either set a bad example or spoil an infant in pampered luxury. 
(Cawood 1982:237)."1 "Ridebantur a maioribus hominibus usque ab ipsis parentibus, qui mihi accidere mali nihil volebant, plagae meae, magnum tunc et grave malum meum" [My beatings, a great and grave burden to me, were laughed at by all my elders, from my very parents down, who really did not want harm to befall me] (Conf. 1.14) and he laments that no-one can consider the torments of hell as lightly as parents deride the punishments inflicted on boys by their schoolmasters: "...quemadmodum parentes nostri ridebant tormenta, quibus pueri a magistris affligebamur" (Conf. 1.15).

Augustine's mother was a Christian, his father probably not, although he was sympathetic, and did not discourage his son from believing in Christ (Conf. 1.17). From this we may deduce that Augustine favoured a Christian upbringing, where Christian parents set the right example as worthy role-models whose conduct would edify their children (cf. de Vries 1978:90, 102). Although the morals of Augustine's parents are not in question, one may query the underlying motive of elders who would subject a little boy to the kind of mental torture and condone the kind of physical abuse which the author recalls.

\section{THE DUTY OF THE TEACHER}

Smail (1938:xlviii) points out that throughout the Institutio Oratoria Quintilian "was not content with merely technical training but aimed at imparting to his pupils all that is implied in the word humanitas...'Humane' or 'liberal' studies alone possess that openness of spirit, that liveliness of sympathy, that knowledge of the human heart, that love of the beautiful, which raise man above his instincts and establish his dignity." This 'liberal' training will nourish the imagination and the spirit. Along with this, Quintilian insisted, the child's will must be trained and his character built (id. p. xlix) (Cf. De Vries 1978:39).

It is generally accepted that children should start their (informal) education as soon as possible because they are the most susceptible to learning new things in the first six years of their lives. In South Africa today most pupils' formal schooling starts in its seventh year. Researchers agree that this is the age when there is a change in the child's intellectual faculty and method of learning. The child also develops his capacity for reasoning at this stage (Louw 1984:292-294). Quintilian advocates an earlier start, citing and discussing earlier authors' opinions. He favours the Greek Chrysippus, who advocates that formal tuition should commence at the age of three (Inst. Or. 1.1.15-16),12 which modern educators believe is too early (see above).

The underlying premise of Quintilian's disquisition is that the child must be placed in the care of a good teacher, a man of character (Inst. Or. 2.2.1). What he has to say about such

11 Needs for esteem arise from the desire to feel adequate, competent, and capable. Such needs are met when individuals are successful in their endeavors and when their success is acknowledged by others. In general, people's needs for esteem are met through recognition of their competence.

12 Another reason why the education of children should start as soon as possible is because children are strong and have boundless energy. Quintilian postulates that a child's mind is equally energetic and resilient, and does not easily tire, because it is "light", and is moved with little effort. While it does not incline towards study by its own insights, it is susceptible to being formed without being tired: "pondus illis abest nec sese ipsi gravant: sic animi quoque, credo, quia minore conalu moventur nec suo visu studiis insistunt, sed formandos se tantummodo praestant, non similiter fatigantur . Another argument is that they are compliant, and do not measure the amount of work done, but continue readily, as long as they remain interested (Inst. Or. 1.12.10-11). 
a teacher's responsibilities can easily be paraphrased in the terminology of modern "Fundamental Pedagogics" (as in De Vries 1978:87-90).

The teacher cares for and pays attention to the child (Inst. Or. 1.2.15-16). Fair disciplinary actions are important (Inst. Or. 1.2.22, 1.3.13-14). A caring and attentive teacher will not only be concerned about the child and its intellectual and moral development, but will also help the child to develop a realistic and positive self-image. A teacher is also responsible for the pupil's moral development (Inst. Or. 2.2.14). The teacher is a role-model for the child and transfers moral precepts and values through personal behavior and conduct towards the child (Inst. Or. 2.2.3-4). Thus teachers must practise in life what they preach in class (Inst. Or. 2.2.8). The teacher must set high standards through an own example (Inst. Or. 2.2.5). Quintilian emphasises the force of example, which produces the most lasting type of learning. Bad examples create ingrained bad habits, and such is the nature of humanity that few children will unlearn a bad habit once inculcated (Inst. Or. 1.1.5).

Augustine's thoughts on education would also not seem out of place in the traditional South African, particularly the Afrikaans, educational scene (cf. de Vries 1978:90-92). To Augustine the teacher of children must primarily be a Christian. His conduct will have as much influence on the child as that of the parents. The Christian teacher is, however, first of all concerned with the child's acquisition of knowledge and must also reflect a stable system of values because he is also responsible for the moral education of his pupils (de Vries 1978:92).13 A teacher should inspire his pupils to learn by his own enthusiasm, sense of purpose, love for the subject and example (cf Howie 1969a:144,153). Augustine recounts his own pleasure in truth, as a child, and his refusal to be satisfied with deceit (Conf. 1.20.31).

In another work Augustine has the following to say about the teacher-pupil relationship: "Let us then adapt ourselves to our pupils with a love which is at once the love of a brother, of a father and of a mother. When once we are linked to them in heart, the old familiar things will seem new to us. So great is the influence of a sympathetic mind that, when our pupils are affected by us as we speak and we by them as they learn, we dwell in each other and thus both they, as it were, speak within us what they hear, while we after a fashion learn in them what we teach" (The Instruction of the Uninstructed 17 as quoted by Howie, 1969a:151). This unique personal relationship results in a partnership. "Each is both teaching, and learning from the other, since they are linked by a common purpose and in love with the same objectives" (Ibid.). It is clear that such a relationship did not exist between Augustine and his teachers, but that this principle is implied in the Confessiones when Augustine's childhood memories of his teachers are contrasted with what he considers to be a good teacher.

\section{CLASSROOM PRACTICE: DIFFERENTIATION, ENJOYMENT, PUNISHMENT AND DRILL}

Quintilian proceeds from the point of view that every child has the potential to learn and be educated. He denies the validity of the common assumption that only a chosen few merit educational effort. Nam contra plures reperias et faciles in excogitando et ad discendum promptos. Quippe id est homini naturale" [For on the contrary you will find most people

13 "Die goeie moet nie net geken word nie, maar die kind moet ook tot wilsbeheer opgevoed word sodat hy die goeje sal wil en die kwade nie sal wil doen nie." Here St Paul's candid acknowledgement that he finds within himself an inability to do so (Rom. 7.15) is perhaps more realistic than De Vries' fond hope. 
to be quick both in thinking and learning, for this is a natural to mankind] (Inst. Or. 1.1.1).14

The first duty of a skilful teacher is to ascertain the pupil's ability and character (Inst. Or. 1.3.1). The teacher must also take the level of cognitive development of the pupils into consideration (Cawood 1986:104), "not immediately overloading infant learners, but reining in his own powers, and going down to the intellectual level of his hearers" - "non statim onerare infirmitatem discentium, sed temperare vires suas et ad intellectum audientis descendere" (Inst. Or. 1.2.27). - because a child develops gradually. He compares the basic, gradual training of the ideal orator with the gradual nurturing of an infant body which in time grows to adult strength (Inst. Or. 1.1.21). These precepts are in absolute accordance with modern didactic principles (Cf. Louw 1984).

Every child is uniquely different from all others; therefore the abilities, talents, temperament and intellectual gifts of each differ from those of all others. This leads to the conclusion that teaching must be differentiated and individualized to meet different needs of different pupils (Inst. Or. 1.3.6-7). 15 Again these precepts sound very modern. 16

Quintilian displays a thorough grasp of the psychological principles which underlie classroom practice. He knew the importance of creating a secure, physically and psychologically safe atmosphere that would put the children at ease and would make them feel safe. Children respond positively to their studies when their need for safety, love and belonging have been met. He warns a teacher to beware of awakening a hearty dislike for study in his pupil, who is as yet incapable of loving his studies, "qui amare nondum potest". He recommends play and pleasurable questioning, encouragement and the fostering of a healthy form of competition.17 A pupil will be encouraged by assumed success: "contendat interim et saepius vincere se putet; praemiis etiam, quae capit illa aetas, evocetur" [let him try to win now and then, and generally think that he has, and let him be challenged by the kind of rewards that his age enjoys] (Inst. Or. 1.1.20).

Enjoyment, competition, praise, encouragement (as well as fair disciplinary actions ${ }^{18}$ ) create a secure, safe environment, prompting the child to learn. When children feel secure,

14 Cf. Inst. Or. 1.1.3.

15 Cf. Smail 1938:xxxiii. Even though all children are different, also in intellectual abilities, "every man's child deserves equal attention" (Inst. Or. 1.1.24). Consequently the teacher who will almost involuntarily pay more attention to the inquisitive pupil (as described in Inst. Or. 1.3.3) must make a conscious effort to give equal attention to slower pupils.

16 See Cawood et al 1982:103-105: "Die didaktiese beginsel van individualisering" leading to differentiated teaching.

17 All modern teachers are aware of the value of turning an ordinary "question and answer" session into a "Quiz", so beloved of television audiences, especially in the junior secondary phase. Quintilian discusses motivation through healthy competition: "..proderit laudata industria, excitabitur laude aemulatio, turpe ducet cedere pari, pulchrum superasse maiores. Accendunt omnia haec animos... ", showing that all children like to be praised for hard work, compete to deserve such praise, and, while not wanting to be excelled by their peers, strive to exceed them (Inst. Or. 1.2.21-22).

18 Research has shown that pupils want discipline, for knowledge of the boundaries of right and wrong creates a sense of security. "Die simpatieke gesagleiding wat hier veronderstel word, impliseer liefde, vertroue, vermaning en bemoediging, afkeuring en goedkeuring omdat die kind alleenlik aan die hand van 'n begrypende volwassene homself kan ontdek en homself kan word" (De Vries 1978:79), cf. (id.:47-48). 
they are confident and more willing to explore new and unfamiliar things. These techniques are also used to motivate children to study and learn by fostering memory and recall. 19

Pupils remember activities which they enjoyed, and which stimulated their curiosity. Inst. Or. 1.1.20 advises that the child must enjoy his studies. This is best achieved through games, beloved by all young children. In combining games with education in "educational "games", two aims are achieved: firstly the child is studying even though he doesn't know it; secondly the child is developing morally under the watchful eye of the teacher (Inst. Or. 1.3.12-13). These ideas of Quintilian foreshadow the idea of the Kindergarten ("Infants' garden") (Smail 1938:xxxi).

In total contrast to the concept of enjoyment of studies lies the practice of corporal punishment as reported by our North African author. Augustine says: "...if idle in learning,I was beaten. For this was judged right by our forefathers; and many ...framed for us weary paths, through which we were fain to pass" (Conf. 1.14). From this dejected note it is clear that Augustine did not consider the corporal punishment to which he was subjected as conducive to learning. Quintilian approved as little of such an approach as do our modern didactic preceptors (e.g. Docking 1980:229-233).20

A subject that ties in with this, is the system of drill and rote learning. The little Augustine hated learning his multiplication tables. One can imagine the little boy's doleful singsong of the hated tables: "iam vero unum et unum duo, duo et duo quattuor odiosa cantio mihi erat..." [truly, then, "one and one are two, two and two are four" was a chant hateful to me] (Conf. 1.22). To Augustine "rote memorizing is a mere mockery of education... [and] he attacks rote learning, consisting in the unthinking, and therefore meaningless, repetition of words, the 'hateful chanting' which in the Confessiones he condemns as a distressing feature of his own elementary education" (so Howie 1969b:13-14).

Another didactic axiom unfamiliar to Augustine's preceptors is that pupils learn best when they earnestly desire to acquire certain knowledge. Successful learning takes place when the pupil's desire is directed toward the purposeful acquisition of something specific. It is a didactic axiom that the teacher must see to it that "the aim of a lesson [is] clearly understood by the learner and that this aim is voluntarily taken up by him" (Howie 1969b:12). The young Augustine did not experience this kind of teaching: "inde in scholam datus sum, ut discerem litteras, in quibus quid utilitatis esset ignorabam miser" [and so I was delivered up to school, to learn my letters, and I had no idea of what it was for, miserable creature that I was] (Conf. 1.14).

\section{LANGUAGE ACQUISITION AND BILINGUALISM}

Augustine also indicates that he had no clear idea of the value of the "Three R's", and hated learning the basics as much as he hated Greek: "nam illas primas, ubi legere et scribere et numerare discitur, non minus onerosas poenalesque habebam quam omnes graecas" [For those first lessons, when one learns to read and write and count I considered

19 Quintilian on motivation: -...praise gives [the mind] growth and effort increase, and the thought that it is doing something great fills it with joy..." (Inst. Or. 1.2.30).

20 Although evidence suggests that corporal punishment is not an effective deterrent, it is the one form of punishment which still arouses the most controversy. Nowadays, the arguments for and against corporal punishment assume its use as the very last resort - though whether this is so in practice has been questioned by Newell (1972; 1979; Docking 1980:229-233). 
just as burdensome as my study of Greek] (Conf. 1.20). Yet he later realized that the acquisition of these skills had been of the utmost importance and had facilitated his ability to pursue his own bent in both research and composition.21

At the opposite end of the learning spectrum lies "natural acquisition" of knowledge, particularly of languages. It has recently once more become didactically fashionable to accept that a child can acquire two languages at the same time without confusion. The brain has the ability to distinguish between two languages. Since the beginning of this century there has been fierce international argument against acceptance of this assumption, which in multilingual South Africa appears almost axiomatic (Richards \& Rogers 1986:137-138). Quintilian was aware of this phenomenon and therefore advises parents consciously to start their children with Greek, as Latin is so pervasive that they would absorb it anyway, even if forbidden to do so (Inst. Or. 1.1.12) adding, "Non longe itaque Latina subsequi debent et cito pariter ire. Ita fiet, ut, cum aequali cura linguam utramque tueri coeperimus, neutra alteri officiat" [Latin (i.e. "mother-tongue") should follow soon after, and be carried on in tandem (with Greek), and so, when we have started to give equal attention to both languages, it will result in neither impeding the other] (Inst. Or. 1.1.14). In this Quintilian appears in total agreement with the Canadian educational authorities, who have, since the mid-sixties, implemented very successful French-language "immersion classes" for anglophone pupils, where the bulk of teaching is done with French as medium. In some cases English as medium is introduced gradually after several years of instruction, in others the French medium is introduced after initial teaching in English.22

When a child acquires his first language, he does so unconsciously, without learning any rules or syntax, and without having to be taught vocabulary.23 Acquisition of a language differs from learning it in that "learning" requires application of rules of grammar, syntax, and the conscious memorization of vocabulary. This basic difference between "acquisition" and "learning" has a profound implication in education - it is easier to acquire a new language than to learn a new language (Krashen and Terrell 1983, passim). Quintilian was aware of this - "...intra biennium, quam verba recte formare potuerunt, quamvis nullo instante, omnia fere loquuntur; at noviciis nostris per quot annos sermo Latinus repugnat" [Within two years after they can pronounce words correctly, they can say almost anything, though no-one is standing over them: yet how long doesn't it take

21 Teachers should take pupils' natural curiosity and interests into account. In Conf. 1.13.22 Augustine mentions that as a youth he has been more interested in the Aeneid than in reading and writing. Instead of forbidding him to read the Aeneid as his teacher did, the teacher could have involved the pupil's favorite reading matter in his reading and writing lessons, thereby motivating him into taking a greater interest. Teachers should use the interests of the pupils to construct lessons; pupils will do the work and leam almost involuntarily because they are dealing with subject matter that interests them.

22 The most successful model appears to be the "delayed immersion" type. In most cases pupils emerge as fluent bilinguals, and their English is by no means impaired, just as postulated by Quintilian about Latin. A prerequisite is further that pupils must have a positive attitude to their mother tongue, as the politically dominant language of the area. In this, too, the Canadian and Roman spheres coincide (Genesee 1987:passim). Cf. Claassen 1992 on "additive and subtractive bilingualism"; Hakuta (1986) and Vaid (1986) passim.

23 Louw 1984:186: "Die aanleer van taal is een van die mees fassinerende en mees betekenisvolle ontwikkelingstake wat die jong kind bemeester. Hierdie taak om klanke, woorde en grammaties korrekte sinne voort te bring, geskied op die oog af sonder inspanning". Minucius Felix, Oct. 2.1, calls a baby's first words loquellam ipso offensantis linguae fragmine dulciorem, "prattle which is sweeter through the very brokenness of its stumbling little tongue". 
before newly bought slaves can speak Latin!] (Inst. Or. 1.12.9). He therefore urges all parents and teachers to help children acquire Greek as second language as soon as possible, advocating the appointment of a Greek-speaking nanny. He explains that the child can acquire Latin from its parents at a later stage.

Augustine was equally aware of the superiority of "language acquisition" above "language learning". He applied the principle of natural acquisition to all aspects of learning. "The method, by which the young child learns his own native language without systematic instruction, seems to Augustine to exemplify the principle of all effective learning. By contrast he holds [that] the formal methods of the schools, in which theory is first expounded and opportunities for practice later provided, is unsound" (Howie 1969a:161). Yet in his North African environment it appears that the young Augustine was never granted the opportunity to acquire second language Greek "naturally", and he reports on the agonies which he experienced in reading Homer and the other Greek authors, whereas the reading of Latin authors was sheer delight (Conf. 1.20-21).

Augustine pretends to be writing autobiographically, but admits that he is basing what he says about his own early development on his observation of others. His particularization of the general shows a great understanding of mother tongue (first language) acquisition by young children. A baby does not merely imitate words that have been spoken to him, but actually generates language: "...little by little, I became conscious where I was; and to wish to express my wishes to those who would content them, and I could not; for the wishes were within me, and they without; nor could they by any sense of theirs enter within my spirit. So I flung about at random limbs and voice, making the few signs I could, and such as I could, like, though in truth very little like, what I wished...So have I learnt infants to be from observing them..." (Conf. 1.8, transl. Pusey). It is commonly held today that in approximately the first three weeks of a baby's life there is reflexive vocalizing. Augustine does not refer to this phase; he starts at the next, where sounds are linked to body conditions and external stimuli (3-6 weeks). This phase progresses into the "babbling phase" (also described in the above passage). During this phase sounds are meaningful and directed.

The modern term for the next phase is "echolalia". Now the baby consciously imitates sounds around him and directs these sounds to specific things around him. "It was not that my elders taught me words in any set method; but I, longing by cries and broken accents and various motions of my limbs to express my thoughts, that so I might have my will, and yet unable to express all I willed, or to whom I willed, did myself, by the understanding which Thou, my God, gavest me, practise the sounds in my memory. When they named any thing, and as they turned towards it, I saw and remembered that they called what they would point out, by the name they uttered. And that they meant this thing and no other, was plain from the motion of their body, the natural language, ...expressed by the countenance, glances of the eye, gestures of the limbs, and the tones of the voice, indicating the affections of the mind, as it pursues, possesses, rejects, or shuns. And thus by constantly hearing words, as they occurred in various sentences, I collected gradually for what they stood;... and having broken in my mouth to these signs, I thereby gave utterance to my will" (Conf. 1.13, transl. Pusey). Here Augustine is referring to what is now termed the "holophrastic" phase, which develops when the child is about a year old. In this phase the child utters only one word at a time; but soon afterwards it progresses to two word utterances. By approximately four years of age the child has acquired the basic structures of his mother tongue (Louw 1984:187-188). 


\section{WRITING AND READING}

Not all skills are naturally acquired. Perhaps the most basic skill that needs conscious teaching, is writing. Quintilian is extremely critical of any rote memorization of the alphabet before pupils are familiar with the relation between the shapes and sounds of letters. Here too Quintilian's suggestions appear surprisingly modern, and in line with the principle of progression from "large arm-movements", to training of the hand, to careful writing between lines. He advocates a system whereby, as first step, young children are provided with ivory letters to play with, in order to familiarize them with the shapes of the letters. Next they should be provided with a wooden tablet on which letters are excised, along the lines of which they can run their stylus, to get the "feel" of the letters, before trying to write on a slate or a wax tablet (Inst. Or. 1.1.25-7). In schools propagated by the Italian educator Pestalozzi, young children are given outlines of letters done in sandpaper pasted on a smooth surface - by fingering the contrasting textures they physically learn the shapes of their letters.

Modern educational theory, since Dewey (who was heavily influenced by Rousseau), has held that writing and reading are mechanical skills where content is negligible.24 Quintilian would have differed. Effective learning always has a clear purpose, of which pupils must be made aware. Thus he advocates the work done in class must have sense. Even basic writing exercises must carry meaning: "...versus, qui ad imitationem scribendi proponentur, non otiosas velim sententias habeant sed honestum aliquid monentes " II should wish that the verses, which are set him to copy, should not contain useless ideas, but should teach something uplifting] (Inst. Or. 1.1.35). The small Augustine's teachers seem to have been unaware of this or they did not manage to convey it to him (see above). One may further deduce that Quintilian would have frowned upon the system of punishment, so much beloved by our Victorian predecessors, of repeatedly "writing out lines". Even the first words to be practised should be relatively rare, even difficult, and requiring explanation, he advised, so that the pupils' graphic effort may later show intellectual dividends, creating, in modern parlance, a "known" on which new "unknowns" - may later be based (ibid. 35).

Reading and writing should always be considered together. In the Inst. Or. 1.1.24-31 Quintilian discusses teaching reading skills. His system may appear somewhat strange to modern readers. First only syllables should be taught, and from this the pupil learns to read. He is critical of any attempts to teach the alphabet by rote, before the sounds of letters and syllables are understood. This system lies somewhere between "phonetic reading" and the recent modern trend, initially based on the ideas of the so-called Gestalttheorists, of teaching a pupil first to "read" whole sentences, then words, and last, to progress towards association of individual letters with sounds. Syllabic teaching would probably not work very well for English, where pronunciation and spelling of words are sometimes widely deviant, and are also not consistent. In Afrikaans, where a system of diphthongs is very prominent, and sound-combinations are consistently taught, or in the Black African languages, which have consistent, phonetic spelling, Quintilian's system might very well succeed.

\section{TEACHING PRINCIPLES: PROGRESSION, VARIETY AND PLAY}

Quintilian describes the negative effect of insufficient establishment of newly gained knowledge before unfamiliar work is embarked upon. To reinforce gained knowledge or

24 This is severely criticized by Hirsch (1987), in his discussion of "cultural literacy". 
skills, practice is required, even for learning to read from left to right, which does not come from reason, but from habit: "Nam prospicere in dextrum... non rationis modo sed usus quoque est... " [For to look towards the right is not a cerebral but only a customary matter] (Inst. Or. 1.1.34). The best sphere for practice and the honing of such skills is within the child's peer group - "Utile igitur habere, quos imitari primum, mox vincere velis" [It's useful therefore that he should have friends, first to imitate, and eventually to rival] (Inst. Or. 1.2.29). In such surroundings, learning is rapid and pleasant.

Quintilian stresses that initial reading should be slow, and progress gradual, until an acceptable pace is attained (Inst. Or. 1.1.32). Balance is important and the pupil must not be overburdened, especially with too many writing exercises. Yet children have a great capacity for study, and are not easily tired, if they are interested in something. The teacher must give only enough information to stimulate pupils to want to learn more. Yet his time must not be "wasted" on geometrical minutiae or singing and dancing (Inst. Or. 1.12.1314). The modern educator may differ with Quintilian on this last point.

Quintilian also recognizes the fact that knowledge must be accumulated gradually, over years. Consequently he advocates an early start, arguing that, however true it may be that an older pupil will learn faster, whatever is learned a year early is a gain, and leaves time in the next year for more difficult studies. This precept is apparently adhered to more closely in Great Britain today, where formal schooling starts at age four and continues to sixteen than in South Africa where the accepted age is often taken to be nearer to seven, with a consequent older matriculation. Quintilian argues that the pupil in this way gradually builds up a basis for a greater complex of knowledge, than could be acquired in one year: "Nam certe quamlibet parvum sit, quod contulerit aetes prior, maiora tamen aliqua discet puer ipso illo anno, quo minora didicisset. Hoc per singulos prorogatum in summam proficit, et quantum in infantia praesumptum est temporis, adolescentiae adquiritur [For certainly, although an early age he can't learn much, a boy learns some bigger things even in the year in which he learned little things. And this, when it is gradually extended, is an ultimate gain, and all the time that was taken up ahead in his infancy, is of advantage to him as adolescent] (Inst. Or. 1.1.18-19). As knowledge is accumulated, the abilities of the child increase. Thus it is very important that the basic knowledge, on which everything else is built, should be appropriate, and well established before anything new is embarked upon.

Variation of activities is a way to combat tedium. The fact that children can pay only so much attention to a particular subject before developing a distaste for it, leads to the conclusion that diversity in subjects as well as activities is very important. Quintilian comments on the ability of people to do more than one thing at a time - "eodem tempore tamen tradi omnia et percipi possint" (Everything can be both perceived and conveyed at the same time) - because the "capacities of the human mind are so swift and nimble and versatile, it cannot be restricted to doing one thing only, but [it] insists on devoting its attention to several different subjects not merely in one day, but actually at one and the same time" (Inst. Or. 1.12.1-2, transl. Watson).

Modern research has shown that the normal concentration span of a pupil is approximately 20 minutes. Any break (even if it is only to pick up a pencil) after 20 minutes refreshes and restores its mind, leading to renewed concentration. Quintilian has the following to say on this topic: "We must remember that variety serves to refresh and restore the mind, and that it is really considerably harder to work at one subject without intermission. Consequently we should give the pen a rest by turning to read, and relieve the tedium of reading by changes of subject. However manifold our activities, in a certain sense we come fresh to each new subject" (Inst. Or. 1.12.4-5, trans. Watson). 
Quintilian further stresses the fact that there must always be a balance between work and play - "nec me offenderit lusus in pueris" [nor would play in children bother me] (Inst. Or. 1.3.10). The value of games is axiomatic; to quote Smail on Quintilian's views: "games are not an end in themselves but [are] a means to increased efficiency...Games sharpen the wits and are a valuable index of character; the wise teacher will study his pupils on the playing-field as well as in the classroom" (1938:xxxiii-iv). "Play" implies not only games, but also vacation times, that is, days spent away from formal study. "Danda est tamen omnibus aliqua remissio; non solum quia nulla res est, quae perferre possit continuum laborem. ... sed quod studium discendi voluntate, quae cogi non potest, constat. Itaque et virium plus adferunt ad discendum renovati ac recentes et acriorem animum, qui fere necessitatibus repugnat" [Yet all must get some relaxation; not only because there is nothing that can bear unbroken labour, but because the desire to learn depends on the will, which cannot be forced. And so pupils bring more liveliness to their study, and a sharper intellect, if they are refreshed] (Inst. Or. 1.3.8-9). Thus holidays and games are necessary for the children to take a break from school-work, to rest and refresh thernselves, to return to school with greater energy.

It is now acknowledged that the "play-way" is a very effective learning mechanism. Augustine knew this instinctively, but his masters apparently did not: "our sole delight was play; and for this we were punished..." (1.9.15). Games have many purposes. First, they enhance communication, and second, games provide a change of activity, counteracting the usual loss of concentration which comes after a period of intensive study and retroactive inhibition.25

\section{ON PUPILS' CAPACITY TO TEACH THEMSELVES}

"... memoria vel ingenium, quae nos habere voluisti pro illa aetate satis..." [...memory or intelligence, which we wanted to consider as sufficient for (a child of) that age...](Conf. 1.9.15). Like Quintilian, Augustine believed that children have a great capacity for learning, and that it must be developed.26 It was shown above that Augustine saw the way a child acquires his mother tongue as the only effective way of learning. The method of developing the child's capacity naturally, as described by Augustine, is nowadays termed the "activity" or "direct" method.27

"[This method] insists that the child be directly engaged with the thing to be known. [Consequently the teacher is in] a peripheral position in the process of learning. It is the learner himself who is central; he teaches himself in a direct encounter with the thing to be known" (Howie 1969a:158-159). This learner-centredness results in the teacher being the facilitator, providing opportunities, stimuli and source materials for pupils' own exploration of the matter to be learnt. The direct method can work only when teaching is differentiated, as each child is his own main educator, with the teacher in the background to help, lead and support. The amount of work, the level of difficulty, and the subject matter will mainly be determined by the pupil's needs, interests, and potential. Of course such an approach should be tempered by the teacher's superior experience of what is desirable (De Vries 1978:65-68). Augustine's own inclination toward Latin literature and

25 The normal concentration span of humans is approximately 20 minutes, after which there must be a change in activity, or "retroactive inhibition" will set in. Retroactive inhibition is the loss of information because of new information that has been stored more recently in the memory. 
his aversion to the Greek is an example of such personal choice, which in his case he was not allowed to pursue (Conf. 1.23). It is a moot point whether, in general, he would have been a better or worse wielder of Latin if he had been allowed to follow his bent and wholly ignore Greek literature.

From all this we may deduce that the tenor of Augustines's earliest memories might have been vastly different if his teachers had paid closer attention to certain valuable educational precepts and principles, which do not belong to this "child-centred" century alone, but had been expounded at least three hundred years before the unhappy little North African boy retreated into himself in misery when his elders taunted him for his juvenile ignorance or beat him for an understandable lack of application.

In conclusion, most educators today will agree that the highest ideal of educators is still to instil in their charges a thirst after pure knowledge. Quintilian advises that an orator should "seek the stable and lasting rewards which his own soul and knowledge and contemplation can give" (Inst. Or. 1.12.18). Pupils must develop an appreciation for the importance of knowledge for knowledge' sake alone. This ideal is, however, in the daily grind of school life, seldom fully realised. It seems that the young Augustine realised it only after escaping from the trammels and travails of the schoolroom, and even then, after his conversion, it continued to elude him, in the sense that his Christian conscience made him query somewhat guiltily the usefulness of the studies towards which his whole heart yearned.28 That his works are redolent of the effects of his education is a greater compliment to his intellect than to the ability of his harsh teachers; of whom neither we nor Quintilian can approve.

\section{BIBLIOGRAPHY}

Butler, H.E. 1920. The Institutio Oratoria of Quintilian. New York, G.P.Putnam's Sons.

Cawood, J., Muller, F.B., Swartz, J.F.A. 1982. Grondbeginsels van die didaktiek. Goodwood: Nasou beperk.

Claassen, J.M 1992. "The teaching of Latin in a multicultural society; problems and possibilities." Scholia NS 1, 102-118.

De Vries, C.G. 1978. Orientering in die fundamentele opvoedkunde, Stellenbosch, UUB.

Docking, J.W. 1980. Control and discipline in schools. Perspectives and approaches. London: Harper \& Row.

Genesee, Fred 1987. Learning through two languages: studies of immersion and biiingual education. Cambridge: Mass., Newbury House.

Hakuta, Kenji 1986. Mirror of language: the debate on bilingualism. New York: Basic Books.

Hirsch, E.D. 1987. Cultural Literacy: what every American needs to know. Boston: Houghton Mifflin.

Howie, G. 1969a. Educational Theory and Practice in St.Augustine. London: Routledge and Kegan Paul.

28 He goes so far as to castigate secular study, particularly myth and epic, as a "hellish torrent" (Conf. 1.26, transl. Pusey). 
Howie, G. 1969b. St.Augustine: On Education. Chicago: Henry Regnery Company.

Krashen, D. and Tracey D. Terrell 1983. The natural approach: language acquisition in the classroom. Oxford: Pergamon.

Louw, D.A. et al 1984. Menslike ontwikkeling. Pretoria: HAUM.

Mans, M.J. 1972. Quintilianus as vertolker van die pedagogiese denke van sy tyd. M.Diss. Potchefstroomse Universiteit vir CHO.

Manson, Michel 1983. "The emergence of the small child in Rome (Third century BC first century AD)." History of Education 12(3), 149-159.

Pusey, E.B. (ed. and transl.) 1953. The Confessions of St.Augustine. London: J.M.Dent and Sons Ltd.

Richards, J.C. \& Rodgers, T.S. 1986. Approaches and methods in language teaching. Cambridge: Cambridge University Press.

Rosenthal, R. \& Jacobson, L. 1968. Pygmalion in the classroom, New York: Holt, Rinehart \& Winston.

Sizoo, A. 1948. Augustinus' Confessiones. Delft: Naamlooze Vennootschap W.D.Meinema.

Smail, W.M. 1938. Quintilian on Education. New York: Oxford University Press.

Vaid, Jyotsna 1986. Language processing in bilinguals: psycholinguistic and neuropsychological perspectives. Hillsdale: N.J., Lawrence Erlbaum.

Watson, J.M. 1907. Quintilian's Institutes of Oratory; or, the education of an orator, in twelve books. London: George Bell. 